\title{
ADVISORY BOARD MEMBERS FOR BOOK
}

Hisamitsu Arai. Secretary-General, Intellectual Property Strategy Headquarters, Cabinet Secretariat, Government of Japan; former Commissioner for the Japan Patent Office; former Vice-Minister for International Affairs, METI

Thomas Cottier. Managing Director, World Trade Institute, Geneva; Professor of European and International Economic Law, and Director of the Institute of European and International Economic Law, University of Bern; former head of legal services, GATT; former member, GATT/WTO dispute settlement panels

Glen Fukushima. President and CEO, Airbus Japan; Governor (former President), American Chamber of Commerce in Japan, Tokyo; former official, United States Trade Representative

Merit Janow. Professor in the Practice of International Economic Law and International Affairs, School of International and Public Affairs, Columbia University; Member, WTO Appellate Body; former official, United States Trade Representative Ed Lincoln. Clinical Professor of Economics and Director, Center for Japan-U.S. Business and Economic Studies: Leonard N. Stern School of Business, New York University; former Senior Fellow, Asian and Economic Studies, Council on Foreign Relations, Washington, D.C.; former Senior Fellow, Brookings Institution; former Special Economic Advisor, United States Embassy, Tokyo

Mitsuo Matsushita. Attorney-at-law and Adviser, Nagashima Ohno \& Tsunematsu; Professor of Law, Seikei University; Professor Emeritus, Tokyo University; former member, WTO Appellate Body

Jeffrey Schott. Senior Fellow, Peterson Institute for International Economics, Washington, D.C.; former Senior Associate, Carnegie Endowment for International Peace; former official, United States Treasury Department 
